\title{
PENGARUH FAKTOR PRODUKSI TERHADAP HASIL PRODUKSI KUE BAKPIA DI DUSUN WARUREJO KECAMATAN GEMPOL KABUPATEN PASURUAN
}

Shella Widya Ningrum ${ }^{1}$, Hety Mustika Ani ${ }^{1}$, Wiwin Hartanto ${ }^{1}$,

${ }^{1}$ Program Studi Pendidikan Ekonomi, Fakultas Keguruan dan Ilmu Pendidikan, Universitas Jember e-mail: hetymustika@yahoo.co.id

\begin{abstract}
Abstrak
Penelitian ini dilakukan untuk mengetahui pengaruh signifikan faktor produksi terhadap hasil produksi kue bakpia di Dusun Warurejo Kecamatan Gempol Kabupaten Pasuruan. Penentuan lokasi penelitian menggunakan metode purposive area. Penentuan responden menggunakan metode populasi sebanyak 55 responden. Pengumpulan data menggunakan metode angket dan dokumen. Analisis data yang digunakan dalam penelitian ini adalah analisis inferensial yang terdiri dari regresi linier sederhana, varian garis regresi, uji $\mathrm{F}$, dan efektivitas garis regresi. Hasil penelitian menunjukkan bahwa analisis regresi linier sederhana menghasilkan persamaan $\mathrm{Y}=4,275+0,257 \mathrm{X}$ dengan nilai Rsquare sebesar 0,849 , nilai Fhitung sebesar 297,196, Ftabel sebesar 2,78 pada taraf signifikansi 0,05 dengan kriteria pengujian yaitu Fhitung > Ftabel maka Ho ditolak dan jika sig $<\alpha$, maka Ho ditolak. Hal tersebut menunjukkan bahwa faktor produksi memiliki pengaruh yang signifikan terhadap hasil produksi kue bakpia di Dusun Warurejo Kecamatan Gempol Kabupaten Pasuruan dengan pengaruh sebesar 84,9\%, sedangkan sisanya 15,1\% dipengaruhi oleh variabel lain yang tidak diteliti.
\end{abstract}

Kata Kunci: Faktor Produksi, Hasil Produksi, Kue Bakpia

\section{PENDAHULUAN}

Home industry tidak pernah lepas dari kegiatan produksi. Kegiatan produksi tidak akan terlaksana tanpa adanya orang yang mengerjakan, barang atau alat-alat yang digunakan untuk memproduksi suatu barang sebagai penunjangnya. Kegiatan produksi dalam penggunaan faktor-faktor produksi harus digabungkan, artinya antara faktor produksi yang satu dengan yang lainnya tidak dapat berdiri sendiri tetapi harus dikombinasikan.

Penggunaan faktor produksi pada usaha home industry umumnya kurang dimanfaatkan secara maksimal sehingga hasil produksi perusahaan tidak dapat dimaksimalkan. Faktor produksi seperti tenaga kerja, bahan baku dan teknologi yang digunakan perusahaan home industry umumnya terbatas jika dibandingkan dengan industri besar, sehingga perlu adanya kiat-kiat tertentu agar perusahaan mampu memaksimalkan penggunaan faktor produksi yang digunakan.

Perusahaan erat kaitannya dengan kegiatan produksi. Menurut Fahmi (2016:2) produksi merupakan sesuatu yang dihasilkan oleh suatu perusahaan baik berbentu barang (goods) maupun jasa (services) dalam suatu periode waktu yang selanjutnya dihitung sebagai nilai tambah bagi perusahaan. Beberapa faktor produksi atau input yang digunakan akan menghasilkan output (keluaran). Hubungan antara jumlah penggunaan input dan jumlah output yang dihasilkan, dengan teknologi tertentu, disebut fungsi produksi. Menurut Boediono (2016:64) fungsi produksi adalah suatu fungsi atau persamaan yang menunjukkan hubungan antara tingkat output dan tingkat (dan kombinasi) penggunaan input-input.

Faktor yang mempengaruhi berkembangnya suatu industri meliputi modal, tenaga kerja, bahan baku, bahan bakar, dan transportasi (Godam, 2006). Penggunaan faktor produksi yang dikombinasikan akan menghasilkan hasil produksi yang maksimal dan efisien. Faktor produksi yang harus dikombinasikan dengan baik yaitu seperti tenaga kerja, bahan baku dan teknologi karena fungsinya yang penting dalam kegiatan produksi kue bakpia di Dusun Warurejo.

Menurut Machfudz (2007:101) hasil produksi adalah hasil akhir dari suatu proses produksi dalam memanfaatkan (mengorbankan) input adalah output atau produk. Hasil produksi atau output menjadi salah satu tolak ukur produktivitas suatu perusahaan yang dapat dilihat dari kuantitas atau kualitas barang yang dihasilkan perusahaan. Hasil produksi kue bakpia harus memiliki kualitas rasa yang enak, daya tahan kue yang lebih lama dan memiliki varian isi dan varian rasa yang beragam serta dilengkapi dengan label resmi dari pemerintah seeprti Depkes, IRT dan halal. 
Berdasarkan pemaparan di atas, maka peneliti bermaksud mengadakan penelitian yang bertujuan untuk mengetahui pengaruh faktor produksi (tenaga kerja, bahan baku dan teknologi) terhadap hasil produksi kue bakpia di dusun Warurejo Kecamatan Gempol Kabupaten Pasuruan.

\section{METODE}

Penelitian ini dilakukan dengan metode kuantitatif menggunakan analisis regresi linier sederhana. Adapun metode penentuan lokasi penelitian menggunakan purposive area dan penentuan sampel menggunakan metode populasi, yaitu seluruh pengusaha kue bakpia di Dusun Warurejo Kecamatan Gempol Kabupaten Pasuruan sebanyak 55 orang. Metode pengumpulan data dengan menggunakan kuesioner tertutup dan dokumen. Analisis data yang digunakan adalah varian garis regresi, Uji F, dan koefisien determinasi, untuk memudahkan perhitungan analisis data maka peneliti menggunakan bantuan program SPSS 23.0 for windows.

\section{HASIL DAN PEMBAHASAN}

\section{Hasil Penelitian}

Hasil perhitungan analisis regresi linier sederhana dengan menggunakan program SPSS 23.0 for windows adalah sebagai berikut:

Tabel 1. Hasil analisis regresi linier sederhana

\begin{tabular}{|c|c|c|}
\hline Variabel Penelitian & Label & Koefisien Regresi \\
\hline A & Konstanta & 4,275 \\
\hline$B$ & Faktor Produksi & 0,257 \\
\hline $\mathrm{R}$ Square : 0,849 & & \\
\hline Multiple $\mathrm{R}: .921^{\mathrm{a}}$ & & \\
\hline F rasio $\quad: 297,126$ & & \\
\hline
\end{tabular}

Berdasarkan data di atas, maka persamaan regresi sederhana yang diperoleh dalam penelitian ini adalah sebagai berikut:

$$
Y=4,275+0,257 X
$$

Adapun hasil perhitungan untuk analisis varian garis regresi adalah sebagai berikut:

Tabel 2. Hasil interpretasi model summary

\begin{tabular}{|l|c|r|r|r|}
\hline Model & R & R Square & $\begin{array}{c}\text { Adjusted R } \\
\text { Square }\end{array}$ & $\begin{array}{c}\text { Std. Error of the } \\
\text { Estimate }\end{array}$ \\
\hline 1 & $.921^{\mathrm{a}}$ & .849 & .846 & .755 \\
\hline
\end{tabular}

a. Predictors: (Constant), faktor produksi

Berdasarkan hasil data yang didapatkan seperti yang terlihat pada tabel di atas, maka diketahui besarnya nilai koefisien korelasi adalah 0,921. Koefisien korelasi sebesar 0,921 tersebut menunjukkan bahwa hubungan antara variabel (X) faktor produksi terhadap variabel (Y) hasil produksi kue bakpia di Dusun Warurejo Kecamatan Gempol Kabupaten Pasuruan dikategorikan mempunyai hubungan yang sangat kuat.

Hasil $R$ Square seperti yang terlihat pada tabel 2 sebesar 0,849, sehingga hasil akhir setelah dimasukkan ke dalam rumus koefisien determinasi $\left(\mathrm{R}^{2}\right)$ adalah sebagai berikut:

$$
R \text { Square } \times 100 \%=0,849 \times 100 \%=\mathbf{8 4 , 9 \%}
$$

Hal ini menunjukkan bahwa besarnya persentase pengaruh faktor produksi terhadap hasil produksi kue bakpia di Dusun Warurejo Kecamatan Gempol Kabupaten Pasuruan sebesar 84,9\%. Adapun perhitungan dari Uji F, diketahui nilai $F_{\text {hitung }}$ sebagai berikut:

Tabel 3. Hasil uji F

\begin{tabular}{cccc}
\hline Variabel & F Change & $\mathrm{F}_{\text {tabel }}$ & Sig F Change \\
\hline X terhadap Y & 297,126 & 2,78 & 0,000 \\
\hline
\end{tabular}


Berdasarkan data di atas, diketahui bahwa nilai $\mathrm{F}_{\text {hitung }}=297,126$ lebih besar dari $\mathrm{F}_{\text {tabel }}=2,78$ dengan tingkat signifikansi 0,000 lebih kecil dari $a=0,05$. Hal ini menunjukkan bahwa faktor produksi memiliki pengaruh yang signifikan terhadap hasil produksi kue bakpia di Dusun Warurejo Kecamatan Gempol Kabupaten Pasuruan.

\section{Pembahasan}

Hasil analisis inferensial yang telah dijabarkan di atas diketahui bahwa faktor produksi dapat memengaruhi hasil produksi kue bakpia di Dusun Warurejo Kecamatan Gempol Kabupaten Pasuruan sebesar 84,9\%. Hasil analisis data menunjukkan bahwa pengusaha kue bakpia di Dusun Warurejo menggunakan faktorfaktor produksi seperti tenaga kerja, bahan baku dan teknologi dalam kegiatan produksi pembuatan kue bakpia setiap hari.

Penggunaan faktor-faktor produksi utamanya penggunaan tenaga kerja, bahan baku dan teknologi sangat membantu kelancaran produksi pembuatan kue bakpia di Dusun Warurejo. Hal tersebut sesuai dengan pendapat (Ghodam, 2006) bahwa faktor yang memengaruhi berkembangnya suatu industri meliputi modal, tenaga kerja, bahan baku, bahan bakar, dan transportasi. Tanpa adanya faktor produksi, maka kegiatan produksi pembuatan kue bakpia akan terganggu.

Tenaga kerja memiliki peran penting dalam kegiatan produksi kue bakpia, tanpa adanya tenaga kerja maka proses produksi tidak berjalan lancar. Hal ini ditunjukkan dengan sebagian besar pengusaha kue bakpia masih menggunakan tenaga kerja khususnya ibu-ibu rumah tangga sekitar. Ibu-ibu rumah tangga tersebut telah memiliki keahlian dan pengalaman kerja yang baik, sehingga mampu membuat kue bakpia yang berkualitas.

Tenaga kerja yang baik adalah tenaga kerja yang bekerja sesuai dengan kemampuan dan keahliannya masing-masing, sehingga penting bagi perusahaan untuk melakukan pembagian tugas para tenaga kerja agar mampu bekerja dengan baik dan hasil produksi dapat maksimal. Hal tersebut sesuai dengan pendapat Adam Smith (1776) yang dikutip Assauri (2008:6) bahwa dengan pembagian kerja (division of labor) terdapat spesialisasi tenaga kerja yang akan menimbulkan peningkatan hasil produksi.

Jam kerja dan usia tenaga kerja juga berpengaruh terhadap kegiatan produksi pembuatan kue bakpia di Warurejo. Jam kerja yang diterapkan pengusaha kue bakpia di Dusun Warurejo umumnya dari jam 07.00 sampai dengan jam 17.00 WIB dengan jam istirahat jam 11.00 sampai dengan jam 13.00 WIB. Hal tersebut sesuai dengan UU No.13/2013 tentang ketenagakerjaan hanya memperbolehkan maksimal jam kerja adalah 40 jam/pekan atau 7 atau 8 jam kerja perhari. Usia tenaga kerja yang sesuai untuk tenaga kerja adalah pada saat usia produktif yaitu dari usia 20 sampai 45 tahun. Usia tenaga kerja yang bekerja di Dusun Warurejo umumnya usia 30 tahun ke atas, sehingga tingkat pengalaman kerja yang dimiliki juga semakin baik, namun untuk usia yang terlalu tua atau diatas 45 tahun meskipun sudah berpengalaman menjadi penghalang dalam kecepatan bekerja karena sudah lanjut usia.

Perusahaan kue bakpia tidak dapat melakukan proses produksi tanpa adanya bahan baku yang tersedia dengan baik. Bahan baku merupakan bahan dasar utama yang digunakan untuk memproduksi kue bakpia, apabila bahan baku yang digunakan kualitasnya rendah maka akan mempengaruhi produk kue bakpia yang dihasilkan perusahaan. Jumlah bahan baku yang digunakan harus efisien, kualitas bahan baku juga perlu diperhatikan karena kualitas bahan baku yang baik tentu menghasilkan produk yang baik pula. Hal tersebut sesuai dengan pendapat Ahyari (1990:264) bahwa kualitas produk yang tinggi merupakan kunci keunggulan bersaing, dimana kualitas bahan bakunya bisa di upayakan dengan cara mengadakan seleksi sumber bahan, pemeriksaan penerimaan barang dan penjagaan gudang bahan bahan baku perusahaan.

Pengusaha kue bakpia di Dusun Warurejo yang mengutamakan kualitas produk kue bakpianya tentu akan menggunakan bahan baku yang berkualitas tinggi dan output yang dihasilkan juga akan lebih baik daripada pengusaha yang menggunakan bahan baku yang berkualitas rendah. Hal tersebut dibuktikan dengan penggunaan bahan baku yang berkualitas yang digunakan mayoritas pengusaha bakpia yaitu tepung Bogasari dan mentega yang digunakan yaitu RoseBrand, sehingga kualitas bahan baku sangat di utamakan dalam produksi kue bakpia di Dusun Warurejo.

Faktor produksi tenaga kerja dan bahan baku memang sangat diperlukan dalam kegiatan produksi kua bakpia, namun adanya teknologi atau mesin mampu mempercepat dan memudahkan proses produksi. Mesin atau teknologi yang digunakan dalam kegiatan produksi kue bakpia pun juga berbeda, namun umumnya pengusaha kue bakpia mengkombinasikan teknologi modern dan teknologi tradisional dalam proses produksinya. Hal tersebut sesuai pendapat Rahardja (2008:102) yang menyatakan bahwa kemajuan teknologi dapat membuat tingkat produktivitas meningkat.

Mesin modern yang telah digunakan pengusaha kue bakpia di Dusun Warurejo adalah mesin pengaduk adonan (mixer) dan oven otomatis. Kegiatan produksi akan lebih terbantu dengan adanya mesin tersebut, sehingga mampu memaksimalkan hasil produksi. Sedangkan alat tradisional yang digunakan pengusaha kue bakpia di Dusun Warurejo adalah cetakan yang masih dibuat dari bambu dan kegiatan pengemasan atau 
packaging masih dilakukan secara manual oleh tenaga kerja agar kue bakpia tidak hancur saat dimasukkan kedalam kardus.

Penggunaan faktor-faktor produksi yang sudah sesuai tentu akan berpengaruh terhadap hasil produksi kue bakpia yang diproduksi. Hasil produksi tersebut kue bakpia dapat dilihat dari segi kuantitas dan kualitas. Dari segi kuantitas para pengusaha kue bakpia mampu menghasilkan output kue bakpia dengan jumlah yang berbeda-beda yaitu berkisar dari 500 sampai dengan 2.000 biji perhari dan akan bertambah banyak saat musim hajatan mampu meningkat menjadi 10 kali lipat yaitu 5.000 hingga 20.000 biji perhari.

Berdasarkan segi kualitas, pengusaha kue bakpia juga memiliki ukuran yang berbeda-beda. Kualitas tersebut dilihat dari varian rasa dan varian isi kue bakpia yang ditawarkan kepada konsumen yang rata-rata memiliki 5 sampai 8 varian isi terlaris yaitu kacang hijau, coklat, tape singkong, pisang keju, pisang coklat, dan varian rasa strawberry, vanilla, durian, nanas dan sebagainya. Daya tahan kue bakpia yang digunakan juga cukup lama sehingga konsumen dapat menikmati kue bakpia lebih lama yaitu sekitar 7 hingga 10 hari. Desain kemasan yang menarik dan dilengkapi dengan plastik serta tanggal kadaluarsa/expired menambah kualitas kue bakpia yang dijual.

Label resmi yang wajib dimiliki pengusaha kue bakpia juga harus dilengkapi. Pengusaha kue bakpia di Dusun Warurejo sudah dilengkapi dengan label-label resmi pemerintah untuk penjualan produk makanan yang lolos uji seperti Depkes, IRT dan Halal. Pengusaha kue bakpia di Dusun Warurejo telah berhasil mengkombinasikan faktor-faktor produksi yang digunakan selama proses produksi kue bakpia untuk menghasilkan output barang dengan maksimal. Hal ini sesuai dengan pendapat Laily dan Pristyadi (2013:53) bahwa tingkat produksi suatu barang tergantung kepada jumlah tenaga kerja, jumlah kekayaan alam dan teknologi yang digunakan.

Berdasarkan pemaparan di atas dapat disimpulkan bahwa faktor produksi (tenaga kerja, bahan baku dan teknologi) berpengaruh signifikan terhadap hasil produksi kue bakpia di Dusun Warurejo Kecamatan Gempol Kabupaten Pasuruan. Berdasarkan hasil perhitungan analisis inferensial di atas, diketahui bahwa besarnya pengaruh tersebut adalah $84,9 \%$ sehingga hipotesis yang diajukan peneliti dapat diterima. Sedangkan sisanya yakni $15,1 \%$ dipengaruhi oleh variabel bebas lain yang tidak diteliti dalam penelitian ini, seperti modal, bahan bakar dan transportasi.

\section{PENUTUP}

Berdasarkan hasil penelitian dan pembahasan yang telah dilakukan maka dapat diambil kesimpulan bahwa faktor produksi memiliki pengaruh yang signifikan terhadap hasil produksi kue bakpia di Dusun Warurejo Kecamatan Gempol Kabupaten Pasuruan. Besarnya persentase pengaruh faktor produksi terhadap hasil produksi kue bakpia di Dusun Warurejo Kecamatan Gempol Kabupaten Pasuruan adalah 84,9\%.

Berdasarkan kesimpulan di atas, maka penulis memberikan saran kepada pengusaha kue bakpia di Dusun Warurejo, diharapkan untuk selalu menggunakan faktor produksi dengan efisien dan sebaik mungkin dengan tujuan agar hasil produksi kue bakpia dapat terus dimaksimalkan dan berkualitasnya semakin baik. Serta saran untuk peneliti lain hendaknya mempertimbangkan sumbangan pengaruh variabel lain yang tidak diteliti dalam penelitian ini sebesar $15,1 \%$ seperti seperti modal, bahan bakar dan transportasi yang mempengaruhi hasil produksi.

\section{DAFTAR PUSTAKA}

Ahyari, Agus. 1987. Manajemen Produksi Pengendalian Produksi Edisi ke 4, Yogyakarta, BPFE

Assauri, Sofjan. 2008. Manajemen Produksi dan Operasi Edisi Revisi 2008. Jakarta: FE UI

Boediono. 2016. Pengantar Ilmu Ekonomi No.1 Ekonomi Mikro. Yogyakarta: BPFE Yogyakarta

Fahmi, Irham. 2016. Manajemen Produksi dan Operasi. Bandung: Penerbit Alfabeta

Godam, 2006. Faktor Pendukung dan Penghambat Industri Bisnis - Perkembangan dan Pembangunan Industri Ilmu Sosial Ekonomi Pembangunan. http://organisasi.org/faktor_pendukung_dan_penghambat_industri_bisnis_perkebangan_dan_pembangun an_industry_ilmu_sosial_ekonomi_pembangunan [Diakses 7 Maret 2018]

Laily, Nur dan Pristyadi, Budiyono. 2013. Teori Ekonomi. Yogyakarta: Graha Ilmu 
Rahardja, Pratama. 2008. Pengantar Ilmu Ekonomi (Makroekonomi dan Mikroekonomi). Jakarta: Lembaga Penerbit Fakultas Ekonomi Universitas Indonesia.

Undang-Undang Republik Indonesia No.13 Tahun 2003 tentang ketenagakerjaan. 